\title{
RADIOCARBON VARIATIONS FROM TASMANIAN CONIFERS: RESULTS FROM THREE EARLY HOLOCENE LOGS
}

\author{
MIKE BARBETTI, ${ }^{1}$ TREVOR BIRD, ${ }^{2}$ GEORGE DOLEZAL, ${ }^{1}$ GILLIAN TAYLOR ${ }^{1}$ \\ ROGER FRANCEY, ${ }^{3}$ EDWARD COOK ${ }^{4}$ and MIKE PETERSON ${ }^{5}$
}

\begin{abstract}
Dendrochronological studies are being carried out on two conifer species in the Stanley River area of western Tasmania. The chronology for Huon pine (Lagarostrobos franklinii), with living trees up to $1400 \mathrm{yr}$ old, extends back to 571 BC. Living celery-top pine (Phyllocladus aspleniifolius) trees are up to $500 \mathrm{yr}$ old. Apart from living or recently felled trees, sections have been taken from 350 subfossil logs preserved in floodplain sediments. They range in age from $>38 \mathrm{ka}$ to modern, with good coverage for the periods 9-3.5 ka and from $2.5 \mathrm{ka}$ to the present. We report here on ${ }^{14} \mathrm{C}$ measurements of decadal samples from three early Holocene logs, between 10 and $9 \mathrm{ka} \mathrm{BP}$, providing short (ca. 300-yr) records of atmospheric ${ }^{14} \mathrm{C}$ variations when plotted against ring numbers. The southern hemisphere data from Tasmania can be compared and wigglematched with published ${ }^{14} \mathrm{C}$ calibration curves from German oak and pine. One set of measurements covers the period, $\mathrm{ca}$. 9280-8990 cal BP, overlapping the link between the Hohenheim "Main 9" and middle Holocene master oak chronologies. The other sets of measurements from Tasmania coincide; they span the period, ca. 9840-9480 cal BP, overlapping the end of the German Preboreal pine and the beginning of the oak chronologies. Our measurements confirm that this part of the calibration curve is a gently sloping ${ }^{14} \mathrm{C}$-age plateau (ca. 8900-8700 BP, between 10,000 and $9500 \mathrm{cal} \mathrm{BP}$ ), and suggest interhemispheric ${ }^{14} \mathrm{C}$ differences close to zero.
\end{abstract}

\section{INTRODUCTION}

Radiocarbon calibration is well established for the Holocene. The differences between tree-ring ages and ${ }^{14} \mathrm{C}$ ages have been determined for the last 11,400 calendar years by high-precision ${ }^{14} \mathrm{C}$ measurements on 10- or 20-ring samples, independently dated by dendrochronology (summarized in Stuiver, Long and $\mathrm{Kra}$ 1993). A small part of the age difference occurs because ${ }^{14} \mathrm{C}$ ages are, by international agreement, calculated using a half-life of $5568 \mathrm{yr}$, which is known to be $c a .3 \%$ too short. Differences apart from this $3 \%$ reflect variations in the production rate and in the exchange of ${ }^{14} \mathrm{C}$ between oceans, atmosphere and biosphere. Most of the Holocene variation is thought to be due to changes in the ${ }^{14} \mathrm{C}$ production rate; the long-term peak-to-trough change is attributed to changes in the Earth's magnetic field strength that affect the cosmic-ray flux. Shorter-term wiggles (with amplitudes of 100 or $200 \mathrm{yr}$ ) are attributed to solar modulation of the cosmic-ray flux.

Late Pleistocene and early Holocene ${ }^{14} \mathrm{C}$ data from southern Germany (Becker and Kromer 1993) are from a 1768-yr-long Preboreal pine chronology. They show short-term wiggles, like those seen in recent millennia, and two plateaus (at $c a .10,100$ and $9600 \mathrm{BP}$ ) with nearly constant ${ }^{14} \mathrm{C}$ ages over several hundred tree rings. The pine chronology overlaps with, and is tentatively matched by dendrochronology to, the German oak master (Becker 1993). Verification of this link by ${ }^{14} \mathrm{C}$ measurements, however, is made difficult by the existence of an additional plateau at $c a .8800 \mathrm{BP}$, where the link occurs.

${ }^{14} \mathrm{C}$ data for times younger than $9150 \mathrm{cal} \mathrm{BP}(7200 \mathrm{BC})$ are on wood from a variety of dendrochronologically dated series (Stuiver, Long and Kra 1993), including the German oak master (Becker 1993). However, many of those data were obtained before the final linkage of the German oak sequence, on series then forming the middle Holocene floating master, which was wiggle-matched to ${ }^{14} \mathrm{C}$ data from bristlecone pine. Two sets of ${ }^{14} \mathrm{C}$ data cover the period around $9000 \mathrm{cal} \mathrm{BP}$; those

\footnotetext{
${ }^{1}$ The NWG Macintosh Centre for Quaternary Dating, Madsen Building F09, University of Sydney, NSW 2006 Australia

${ }^{2}$ Trades Hall, 219 New Town Road, New Town, Tasmania 7008 Australia

${ }^{3}$ CSIRO Division of Atmospheric Research, Private Bag No. 1, Mordialloc, Victoria 3195 Australia

${ }^{4}$ Lamont-Doherty Earth Observatory of Columbia University, Palisades, New York 10964 USA

${ }^{5}$ Forestry Corporation, Hobart, Tasmania 7001 Australia
} 
of Kromer et al. (1986) and Stuiver et al. (1986); they are used in this paper even though they are subject to small revisions (Kromer, personal communication; Stuiver, Long and Kra 1993).

Measurements from the southern hemisphere are essential as an independent verification of the calibration curve, especially in those time windows where different data sets from the northern hemisphere are joined. Our main focus here is to compare the Tasmanian data with the early Holocene records from the northern hemisphere.

Southern hemisphere data are also important because the offset from the northern hemisphere may have varied in earlier times due to changes in global carbon fluxes. The current latitudinal ${ }^{14} \mathrm{C}$ gradient in atmospheric $\mathrm{CO}_{2}$ shows lower (older) values in the northern hemisphere due to fossil fuel releases, and at high northern and southern latitudes due to deep ocean mixing (Levin et al. 1992). At Tasmanian latitudes, $\Delta^{14} \mathrm{C}$ values $\mathrm{ca}$. 4-7\%o higher (30-60 yr younger) than mid-latitudes of the northern hemisphere are observed. Pre-industrially, the southern oceans may have been a net source of $\mathrm{CO}_{2}$ due to the release of "old" carbon, taken up in the North Atlantic ocean and transported over many centuries to the south (Broecker and Peng 1992); thus, southern hemisphere ${ }^{14} \mathrm{C}$ ages may have been "older" than northern hemisphere values, i.e., the modern interhemispheric gradient may have been reversed. Over past centuries, changes in interhemispheric ${ }^{14} \mathrm{C}$ differences might reflect changes in deep water formation, a major uncertainty in current global carbon budgeting (Enting and Mansbridge 1987). The pre-industrial southern hemisphere has been reported at $36 \mathrm{yr}$ older in recent centuries (Lerman, Mook and Vogel 1970; Vogel et al. 1986). We did not find evidence to support such an age offset in our first sets of results from Tasmania, at ca. 8260-7910 cal BP and AD 1600-1800 (Barbetti et al. 1992).

We began dendrochronological studies 13 yr ago on two conifer species in the Stanley River area of western Tasmania (SRT; $145^{\circ} \mathrm{E}, 42^{\circ} \mathrm{S}$; Francey et al. 1984). We sampled living trees as well as logs exposed in the river banks in 1981, and excavated in floodplain sediments between 1982 and 1994. We have now obtained sections from over 350 well-preserved subfossil logs. The chronology for Huon pine (Lagarostrobos franklinii) currently extends from $571 \mathrm{BC}$ to the present. We are beginning to build a floating chronology from 9-3.5 ka BP (calendar years), using the numerous logs with overlapping ages in this period. This has resulted in a 2400 -yr record spanning the period 6 to $3.6 \mathrm{ka}$ cal BP, with several shorter floating sequences in earlier time periods. We have not yet found Huon pine logs between $c a .3 .5$ and $2.5 \mathrm{ka} \mathrm{BP}$, but we hope to close this gap by excavating in nearby areas. One locality has yielded two logs with ages $>38 \mathrm{ka}$, and their wide rings suggest a warm climate; they may be of Last Interglacial age. Living celery-top pine (Phyllocladus aspleniifolius) trees are up to $500 \mathrm{yr}$ old, and about 20 subfossil celery-top logs have been recovered, the oldest of which are two with ages centered at 13.0 and $12.7 \mathrm{ka} \mathrm{BP}$ (SRT-462 and -157; Barbetti et al. 1992). Another log (SRT-444) is centered at $7.3 \mathrm{ka} \mathrm{BP}$; the others are younger but as yet too few to construct a chronology. A single subfossil log of King William pine (Athrotaxis selaginoides), SRT-684, aged $14.3 \mathrm{ka}$ $\mathrm{BP}$, has been recovered. This species no longer grows in the Stanley River Valley.

Four Huon pine logs, SRT-416, -450a, -449 and -447 are between 8 and 9 ka BP ( $c a .9-10 \mathrm{ka} \mathrm{cal} \mathrm{BP),}$ and we present here the results of decadal ${ }^{14} \mathrm{C}$ measurements on three of them. (Only one ${ }^{14} \mathrm{C}$ measurement was taken on SRT-447.)

\section{METHODS}

We polished cross-sections from the logs and split them into consecutive 10-ring samples, except for the innermost and outermost parts, where the rings were narrow, and we took up to 40 rings per sample. We reduced the wood samples to $c a .0 .5 \mathrm{~mm}$ particle size in a cutting mill, and prepared 
holocellulose following the method of Head (1979). We used standard techniques (Gupta and Polach 1985) to prepare benzene samples $(4 \mathrm{ml})$. Stable carbon isotope $\left({ }^{13} \mathrm{C} /{ }^{12} \mathrm{C}\right)$ measurements were made on subsamples of the combustion $\mathrm{CO}_{2}$ at the CSIRO Division of Atmospheric Research.

We made ${ }^{14} \mathrm{C}$ measurements using 7-ml Teflon ${ }^{\otimes}$ vials in a low-level Wallac Quantulus $1220^{\mathrm{TM}}$ liquid scintillation counter. We calculated conventional ${ }^{14} \mathrm{C}$ ages using modern standard values derived from measurements of ANU sucrose and NBS oxalic acid, but we assumed an uncertainty of \pm 0.1 or \pm 0.2 counts $\mathrm{min}^{-1}$ for the standard, considerably larger than the typical Poisson deviation of \pm 0.07 counts $\mathrm{min}^{-1}$ associated with an individual standard measurement. Measurement uncertainties associated with these samples range from $c a . \pm 55$ to $\pm 65 \mathrm{yr}$, depending on the counting time (5000 or $2500 \mathrm{~min}$ ). The measurements reported here were made between June 1990 and May 1992 (except for the earlier pilot results).

\begin{abstract}
Results
${ }^{14} \mathrm{C}$ results (Table 1) from two logs, SRT-416 and -450 a, provide short records of atmospheric ${ }^{14} \mathrm{C}$ variations, 340 and $240 \mathrm{yr}$ long, respectively. Many of the results, especially those from the inner rings, are $c a .8800 \mathrm{BP}$, and thus the two logs appear to overlap in time. Unfortunately, SRT-450a is particularly influenced by lobate growth and wedging, prejudicing convincing tree-ring cross-dating among the ring-width patterns. Thus, we have tried to match them using only the ${ }^{14} \mathrm{C}$ data.

We used a smoothing spline with $50 \%$ attenuation at $30 \mathrm{yr}$ (typically 3 samples) to interpolate the ${ }^{14} \mathrm{C}$ measurements and provide equally spaced data at one ring-number $(=1 \mathrm{yr})$ intervals for each $\log$. The interpolated SRT-450a ring numbers were then stepped relative to SRT-416 ring numbers to obtain the root-mean-square (rms) differences in ${ }^{14} \mathrm{C}$ between the two sets of samples for each step. We obtained a minimum rms difference of 51 yr with SRT-450a ring 0 equivalent to SRT-416 ring 114. Figure 1 shows the results of this normalization with the SRT-416 data and smoothing spline plotted against mid-sample ring number, and the fitted SRT-450a data and smoothing spline superr 'sed. The coincidence of several features in the records, the most marked being the ${ }^{14} \mathrm{C}$ age decline in the outer rings, gives confidence in the matching process. The heavy dark curve, the average of these two smoothing splines, is used for comparison with the northern hemisphere data.
\end{abstract}

Figure 2 shows the results of a comparison of the SRT- 416 and -450 a data with the data from Kromer and Becker (1993). We used a similar approach of minimizing ${ }^{14} \mathrm{C}$ differences. The Preboreal pine and the Hohenheim "Main 9" oak chronologies were merged and fitted with a 30-yr smoothing spline to provide interpolated annual values-Figure $2 \mathrm{~A}$ shows this spline plotted against the Kromer and Becker (1993) age (expressed in calendar years before AD 1950). Also shown in Figure $2 \mathrm{~A}$ is the average SRT-416, -450 a curve of Figure 1, which has been stepped along the German oak curve (taking 1 ring number $=1 \mathrm{yr}$ ) seeking a minimum rms difference in ${ }^{14} \mathrm{C}$. Figure $2 \mathrm{~B}$ illustrates the sequence of rms differences obtained by this procedure. The time axis corresponds to the mean age over the ring segments being compared. Two minima are defined by this process, with rms differences $\sim 69$ yr at -9697 and -9652 yr. To choose between these two minima, we also plotted the mean difference between the ${ }^{14} \mathrm{C}$ values in Figure 2B. The $-9652 \mathrm{yr}$ rms minimum also corresponds to a mean (German-Tasmanian) difference of $-1.5 \mathrm{yr}$, compared to $+28 \mathrm{yr}$ at the $-9697-\mathrm{yr}$ minimum. For this reason, as well as the correspondence in the marked drop in ${ }^{14} \mathrm{C}$ at $-9500 \mathrm{yr}$, we prefer the $-9652 \mathrm{yr}$ rms minimum $\left({ }^{14} \mathrm{C}=8721 \mathrm{BP}\right.$ on the spline fit to the German data), which is the case shown in Figure 2. Here, the SRT-416 ring zero corresponds to $-9838 \mathrm{yr}$ before AD 1950, and SRT-450a ring zero to -9724 yr. Thus, SRT-416 appears to span, and SRT-450a to border, the proposed overlap between the "floating" Preboreal pine, and the anchored M9 oak chronologies of 
TABLE 1. Radiocarbon Dates from Stanley River Huon Pine Logs, SRT-416, -447 and $-450 a^{*}$

\begin{tabular}{|c|c|c|c|c|c|c|}
\hline $\begin{array}{l}\text { SUA- } \\
\text { no. }\end{array}$ & $\begin{array}{l}\text { Tree-ring } \\
\text { span (yr) }\end{array}$ & $\begin{array}{c}\delta^{13} C_{\text {PDB }} \\
\left(\%_{\infty}\right)\end{array}$ & $\begin{array}{c}{ }^{14} \mathrm{C} \\
(\mathrm{yr} \mathrm{BP})\end{array}$ & St. dev. & $\begin{array}{c}\text { Center } \\
\text { ring }\end{array}$ & $\begin{array}{c}\text { Tree ring } \\
\text { (yr BP) }\end{array}$ \\
\hline \multicolumn{5}{|c|}{$S R T-416$} & \multicolumn{2}{|c|}{ Ring 0 at 9838} \\
\hline 5257 & $331-340$ & -23.6 & 8554 & 56 & 336 & -9503 \\
\hline $5161+$ & $316-340$ & -24.6 & 8646 & 41 & 328 & -9510 \\
\hline 5256 & $321-330$ & -23.7 & 8605 & 56 & 326 & -9513 \\
\hline 5255 & $311-320$ & -24.1 & 8745 & 56 & 316 & -9523 \\
\hline 5254 & $301-310$ & -23.8 & 8625 & 56 & 306 & -9533 \\
\hline 5253 & $291-300$ & -24.1 & 8644 & 56 & 296 & -9543 \\
\hline 5252 & $281-290$ & -23.8 & 8845 & 56 & 286 & -9553 \\
\hline 5251 & $271-280$ & -23.6 & 8633 & 55 & 276 & -9563 \\
\hline 5250 & $261-270$ & -24.6 & 8635 & 55 & 266 & -9573 \\
\hline 5249 & $251-260$ & -24.6 & 8667 & 55 & 256 & -9583 \\
\hline 5248 & $241-250$ & -23.8 & 8724 & 55 & 246 & -9593 \\
\hline 5247 & $231-240$ & -24.2 & 8799 & 55 & 236 & -9603 \\
\hline 5246 & $221-230$ & -24.4 & 8817 & 55 & 226 & -9613 \\
\hline 5245 & $211-220$ & -24.5 & 8758 & 55 & 216 & -9623 \\
\hline 5244 & $201-210$ & -24.1 & 8982 & 56 & 206 & -9633 \\
\hline 5243 & $191-200$ & -23.4 & 8836 & 55 & 196 & -9643 \\
\hline 5242 & $181-190$ & -23.9 & 8932 & 56 & 186 & -9653 \\
\hline 5241 & $171-180$ & -23.9 & 8682 & 64 & 176 & -9663 \\
\hline 5240 & $161-170$ & -24.4 & 8769 & 64 & 166 & -9673 \\
\hline 5239 & $151-160$ & -24.8 & 8767 & 64 & 156 & -9683 \\
\hline 5238 & $141-150$ & -24.9 & 8736 & 65 & 146 & -9693 \\
\hline 5237 & $131-140$ & -24.9 & 8841 & 65 & 136 & -9703 \\
\hline 5236 & $121-130$ & -25.1 & 8793 & 65 & 126 & -9713 \\
\hline 5235 & $111-120$ & -25.2 & 8929 & 65 & 116 & -9723 \\
\hline 5234 & $101-110$ & -25.6 & 8814 & 65 & 106 & -9733 \\
\hline 5233 & $91-100$ & -25.5 & 8677 & 65 & 96 & -9743 \\
\hline 5232 & $81-90$ & -25.9 & 8735 & 64 & 86 & -9753 \\
\hline 5231 & $71-80$ & -25.9 & 8760 & 64 & 76 & -9763 \\
\hline 5230 & $61-70$ & -26.5 & 8800 & 65 & 66 & -9773 \\
\hline 5229 & $51-60$ & -26.0 & 8797 & 65 & 56 & -9783 \\
\hline $5228 \ddagger$ & $31-50$ & -25.7 & 8820 & 65 & 41 & -9798 \\
\hline \multirow[t]{2}{*}{$5227 \ddagger$} & $1-30$ & -25.7 & 8895 & 65 & 16 & -9823 \\
\hline & & Averages & 8758 & \multicolumn{3}{|c|}{189} \\
\hline \multicolumn{2}{|l|}{$S R T-447$} & & & & \multicolumn{2}{|c|}{ Ring 0 at 10,064} \\
\hline $5094 \dagger$ & $114-152$ & -24.0 & 8933 & 53 & $133^{\circ}$ & -9931 \\
\hline \multicolumn{2}{|c|}{$S R T-450 a$} & & & & \multicolumn{2}{|c|}{ Ring 0 at 9724} \\
\hline 5209 & $231-242$ & -23.8 & 8538 & 55 & $237^{\circ}$ & -9488 \\
\hline 5210 & $221-230$ & -23.6 & 8553 & 55 & 226 & -9499 \\
\hline $5092 \dagger$ & 19-239 & -24.1 & 8549 & 52 & 219 & -9505 \\
\hline 5211 & $211-220$ & -24.6 & 8795 & 64 & 216 & -9509 \\
\hline 5212 & $201-210$ & -24.6 & 8717 & 64 & 206 & -9519 \\
\hline 5213 & $191-200$ & -24.8 & 8655 & 64 & 196 & -9529 \\
\hline 5214 & $181-190$ & -24.6 & 8697 & 64 & 186 & -9539 \\
\hline 5215 & $171-180$ & -24.6 & 8704 & 64 & 176 & -9549 \\
\hline 5216 & $161-170$ & -24.7 & 8705 & 64 & 166 & -9559 \\
\hline 5217 & $151-160$ & -25.5 & 8687 & 64 & 156 & -9569 \\
\hline 5218 & $141-150$ & -26.0 & 8590 & 64 & 146 & -9579 \\
\hline 5219 & $131-140$ & -25.3 & 8666 & 61 & 136 & -9589 \\
\hline 5220 & $121-130$ & -25.0 & 8688 & 64 & 126 & -9599 \\
\hline $5223 \ddagger$ & $101-120$ & -26.2 & 8814 & 65 & 111 & -9614 \\
\hline $5224 \ddagger$ & $81-100$ & -25.9 & 8823 & 65 & 91 & -9634 \\
\hline \multirow{3}{*}{$\begin{array}{l}5225 \S \\
5226 \S\end{array}$} & $41-80$ & -26.9 & 8784 & 65 & 61 & -9664 \\
\hline & $1-40$ & -26.9 & 8769 & 65 & 21 & -9704 \\
\hline & & Averages & 8690 & & 157 & \\
\hline
\end{tabular}

*10-ring samples unless otherwise noted; $†$ Pilot sample; $\ddagger 20$ - or 30 -ring sample; $\S 40$-ring sample 
STANLEY RIVER SRT-416, SRT-450a

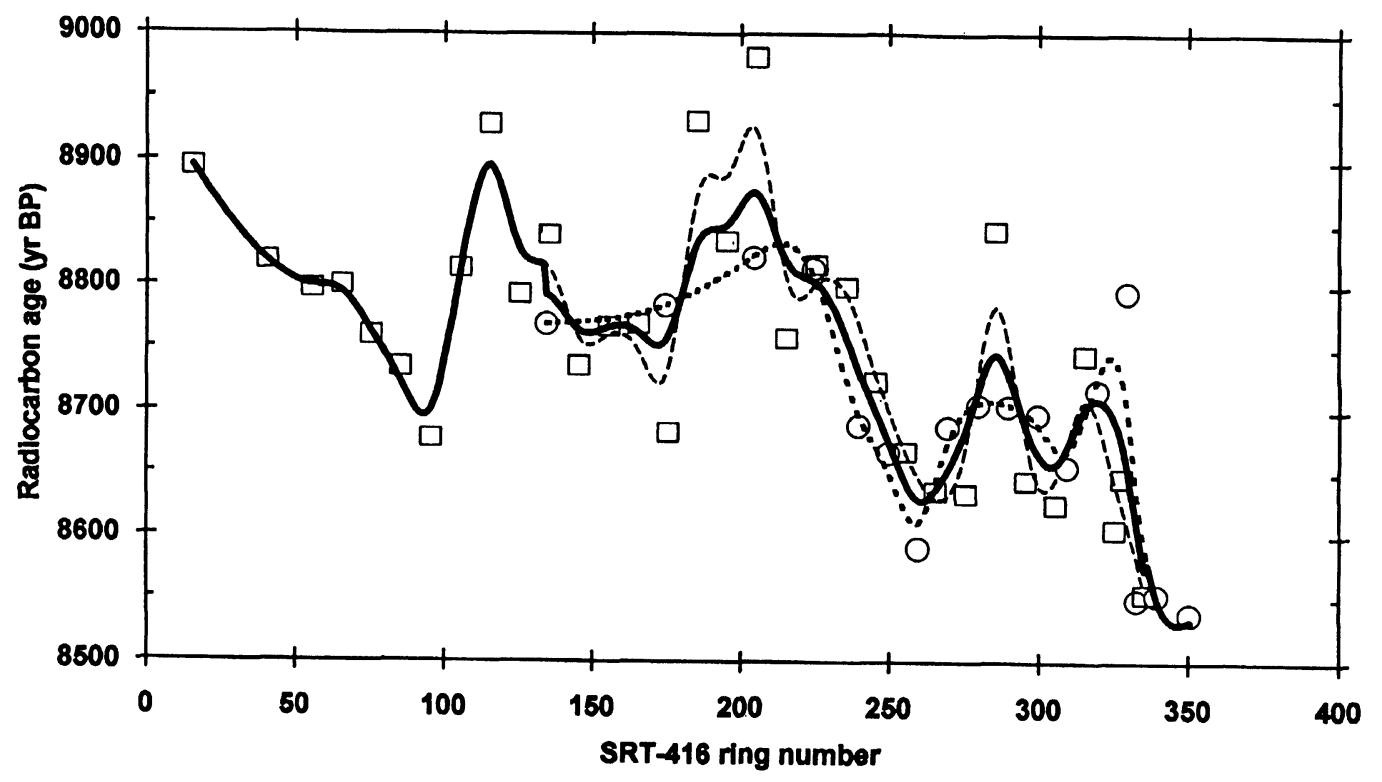

Fig. 1. Merging of the ${ }^{14} \mathrm{C}$ records from two Huon pine logs $\left({ }^{14} \mathrm{C}\right.$ ages $\left.-8800 \mathrm{BP}\right) . \square={ }^{14} \mathrm{C}$ ages from Stanley River Huon pine log SRT-416 plotted $v s$. SRT-416 ring number; $---=$ an interpolating spline with 30 -yr smoothing. and $\cdots=$ similar "time" series from SRT-450a. The SRT-450a data are plotted $v s$. SRT-416 ring number, after fitting by minimization of the rms ${ }^{14} \mathrm{C}$ differences between the logs. $-=$ average of the individual ${ }^{14} \mathrm{C}$ spline series.

Kromer and Becker (1993). Given the importance of confirming this link, plans to re-analyze the SRT logs with high precision at the Heidelberg laboratory are now being implemented. The single determination of a ${ }^{14} \mathrm{C}$ age of 8933 BP for a 39 -yr sample around ring number 133 in SRT-447, which corresponds to -9931 yr before AD 1950 on the spline fit to the Kromer and Becker (1993) data, suggests that this log will substantially contribute to this task.

With the preferred matching represented in Figure $2 \mathrm{~A}$, there is clearly no significant latitudinal difference in ${ }^{14} \mathrm{C}$, although Figure 2B favors a northern hemisphere ${ }^{14} \mathrm{C}$ greater than or equal to that of the southern hemisphere; however, the uncertainties are large (ca. $70 \mathrm{yr})$.

Table 2 lists ${ }^{14} \mathrm{C}$ data for the fourth Huon pine $\log$, SRT-449, and Figure 3 shows the results of applying a similar matching procedure. In this case, a reference spline was constructed by fitting the merged oak chronologies of Kromer et al. (1986), Kromer and Becker (1993) and Stuiver et al. 1986. The measured ${ }^{14} \mathrm{C}$ values for SRT-449, on a time scale corresponding to the rms "best fit", are also superposed. We also obtained dual minima for SRT-449, as in Figure 2B. We preferred a minimum rms difference of $64.5 \mathrm{yr}$ with a mean difference of $-3 \mathrm{yr}$ (oak-Huon) over an rms difference of $65.6 \mathrm{yr}$ with a mean difference $48 \mathrm{yr}$. SRT-449 ring zero corresponds to $-9281 \mathrm{yr}$ before AD 1950 for the preferred solution (and to $-9331 \mathrm{yr}$ for the $48-\mathrm{yr}$ oak excess case).

\section{DISCUSSION AND CONCLUSION}

${ }^{14} \mathrm{C}$ data from the Stanley River and from German Preboreal pine and oak show trend changes on a time scale of a century or two, such as those seen throughout the Holocene. Both data sets show a plateau in the calibration curve, with nearly constant ${ }^{14} \mathrm{C}$ ages ( $\left.c a .8900-8700 \mathrm{BP}\right)$ over five centu- 


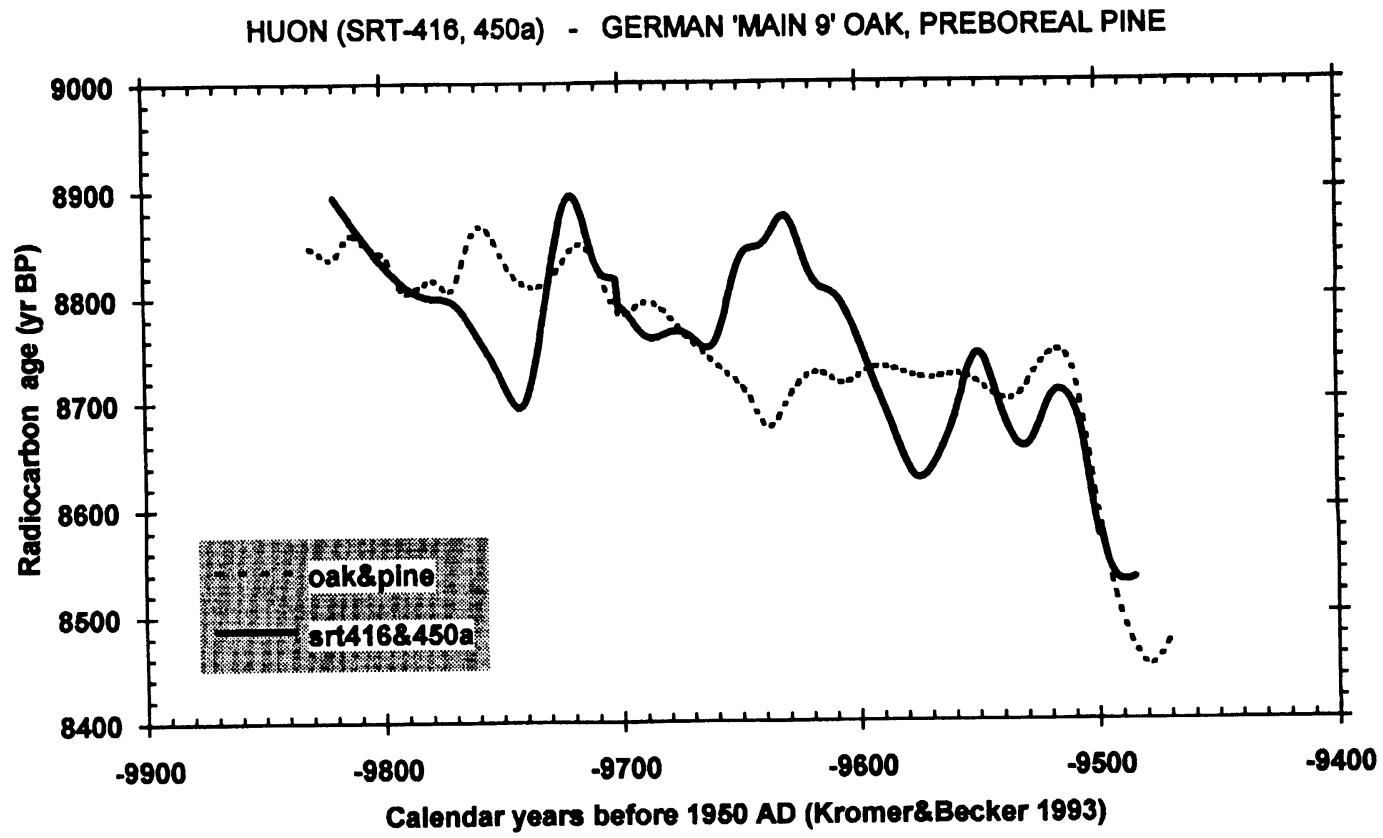

Fig. 2A. Comparison of the $\sim 8800$ BP Huon pine with merged and interpolated data from German Preboreal pine and oak (Kromer and Becker 1993). $=$ merged SRT -416 and $-450 \mathrm{a}{ }^{14} \mathrm{C}$ data from Figure 1, expressed $v s$. calendar years before AD 1950.

HUON (SRT-416,-450a) - GERMAN OAK

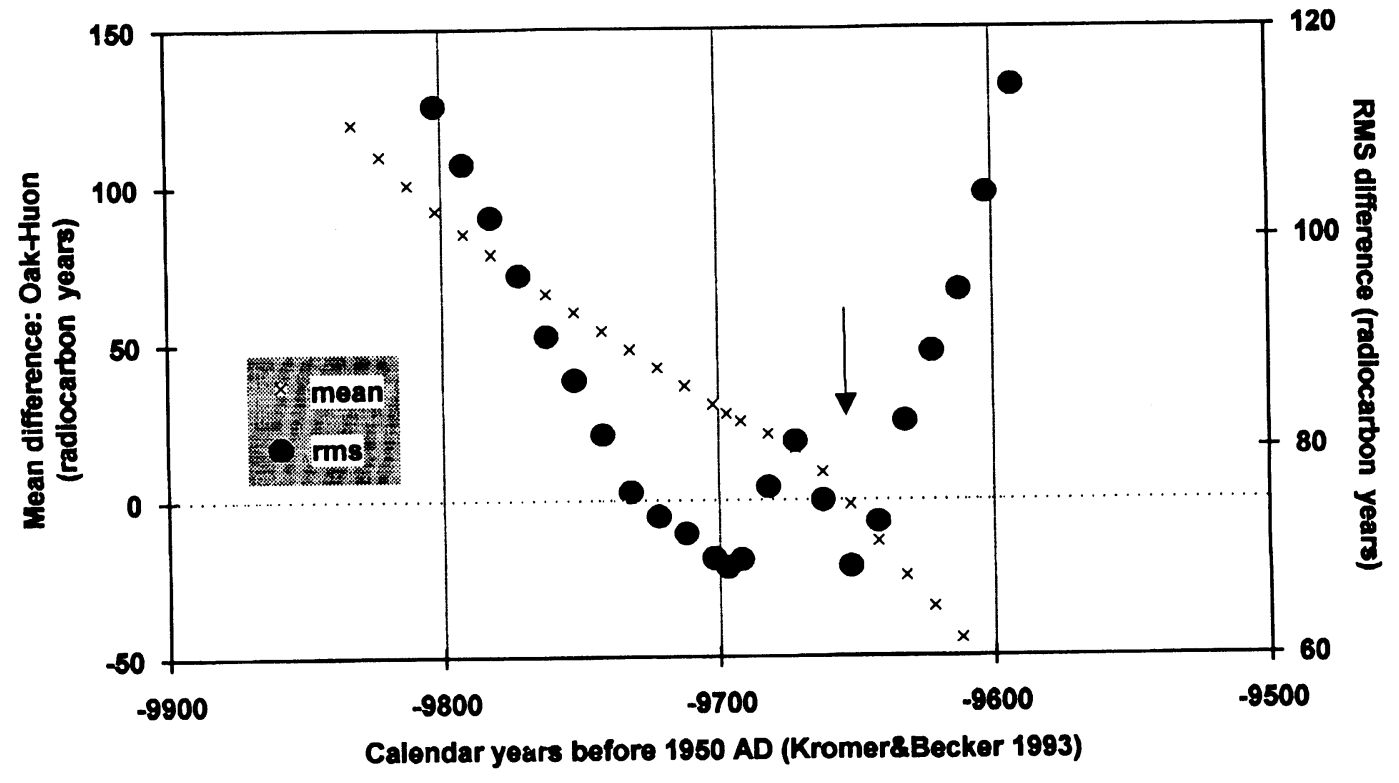

Fig. 2B. The procedure to establish the minimum rms difference between the SRT and German ${ }^{14} \mathrm{C}$ ages; also the mean difference in ${ }^{14} \mathrm{C}$ ages (German-Tasmanian) as the SRT series is moved in time along the German time axis. The arrow indicates the "preferred" solution. 
TABLE 2. Radiocarbon Dates From Stanley River Huon Pine Log SRT-449*

\begin{tabular}{|c|c|c|c|c|c|c|}
\hline $\begin{array}{l}\text { SUA- } \\
\text { no. }\end{array}$ & $\begin{array}{l}\text { Tree-ring } \\
\text { span }(y r)\end{array}$ & $\begin{array}{c}\delta^{13} C_{\text {PDB }} \\
(\% \circ)\end{array}$ & $\begin{array}{c}{ }^{14} \mathrm{C} \\
\text { (yr BP) }\end{array}$ & $\begin{array}{l}\text { St. } \\
\text { dev. }\end{array}$ & $\begin{array}{c}\text { Center } \\
\text { ring }\end{array}$ & $\begin{array}{c}\text { Tree ring } \\
\text { (yr BP) }\end{array}$ \\
\hline $\begin{array}{l}\text { SRT-449 } \\
5091 \dagger \\
5181 \\
5182 \\
5183 \\
5184 \\
5185 \\
5186 \\
5187 \\
5188 \\
5189 \\
5190 \\
5191 \\
5192 \\
5193 \\
5194 \\
5195 \\
5196 \ddagger \\
5197 \\
5198 \ddagger \\
5199 \\
5200 \\
5201 \ddagger \\
5202 \\
5203 \\
5204 \\
5205 \\
5206 \\
5207 \\
5208 \$\end{array}$ & $\begin{array}{c}185-235 \\
281-294 \\
271-280 \\
261-270 \\
251-260 \\
241-250 \\
231-240 \\
221-230 \\
211-220 \\
201-210 \\
191-200 \\
181-190 \\
171-180 \\
161-170 \\
151-160 \\
141-150 \\
131-140 \\
121-130 \\
111-120 \\
101-110 \\
91-100 \\
81-90 \\
71-80 \\
61-70 \\
51-60 \\
41-50 \\
31-40 \\
21-30 \\
1-20\end{array}$ & $\begin{array}{l}-23.2 \\
-22.1 \\
-22.0 \\
-22.3 \\
-22.4 \\
-22.3 \\
-22.7 \\
-22.4 \\
-22.6 \\
-23.2 \\
-23.2 \\
-22.6 \\
-23.0 \\
-22.8 \\
-22.4 \\
-22.4 \\
-22.5 \\
-22.4 \\
-22.6 \\
-22.7 \\
-22.4 \\
-22.3 \\
-22.4 \\
-22.0 \\
-22.2 \\
-22.4 \\
-22.5 \\
-22.2 \\
-22.2 \\
\end{array}$ & $\begin{array}{l}8073 \\
8086 \\
8221 \\
8136 \\
8146 \\
8136 \\
8229 \\
8224 \\
8226 \\
8216 \\
8156 \\
8079 \\
8249 \\
8206 \\
8275 \\
8259 \\
7967 \\
8282 \\
8026 \\
8184 \\
8295 \\
8058 \\
8300 \\
8348 \\
8307 \\
8336 \\
8216 \\
8320 \\
8326 \\
\end{array}$ & $\begin{array}{l}50 \\
54 \\
54 \\
54 \\
54 \\
54 \\
54 \\
54 \\
54 \\
54 \\
55 \\
54 \\
55 \\
54 \\
55 \\
55 \\
54 \\
55 \\
54 \\
55 \\
55 \\
55 \\
55 \\
55 \\
55 \\
55 \\
55 \\
55 \\
55\end{array}$ & $\begin{array}{l}\text { Ring } \\
210 \\
288 \\
276 \\
266 \\
256 \\
246 \\
236 \\
226 \\
216 \\
206 \\
196 \\
186 \\
176 \\
166 \\
156 \\
146 \\
136 \\
126 \\
116 \\
106 \\
96 \\
86 \\
76 \\
66 \\
56 \\
46 \\
36 \\
26 \\
11\end{array}$ & $\begin{array}{c}\text { at } 9281 \\
-9071 \\
-8994 \\
-9006 \\
-9016 \\
-9026 \\
-9036 \\
-9046 \\
-9056 \\
-9066 \\
-9076 \\
-9086 \\
-9096 \\
-9106 \\
-9116 \\
-9126 \\
-9136 \\
-9146 \\
-9156 \\
-9166 \\
-9176 \\
-9186 \\
-9196 \\
-9206 \\
-9216 \\
-9226 \\
-9236 \\
-9246 \\
-9256 \\
-9271\end{array}$ \\
\hline & & Averages & 8224 & & 152 & \\
\hline
\end{tabular}

ries in early Holocene time ( $c a .10$ to 9.5 ka calendar yr BP). This "plateau" region actually has a gentle slope, of $c a \cdot 0.5^{14} \mathrm{C}$ yr for every year.

Tasmanian ${ }^{14} \mathrm{C}$ data from SRT-449 have been matched with ${ }^{14} \mathrm{C}$ data from German oak. When compared with the "Main 9" data (Kromer and Becker 1993), and the unified German oak data (Kromer et al. (1986), with ring 0 at $7230 \mathrm{BC}$; Stuiver $e$ al. (1986), with ring 1 at $7215 \mathrm{BC}$ ), our match places ring 0 of SRT- 449 at $-9281 \mathrm{yr}$ cal BP. Our data then appear, on average, to be slightly but not significantly younger than the data from the northern hemisphere.

Our data from the southern hemisphere for the Holocene indicate little or no offset in ${ }^{14} \mathrm{C}$ concentration when compared with northern hemisphere data. These minimal offsets, with the southern hemi- 
HUON (SRT-448) - OAK (GERMAN)

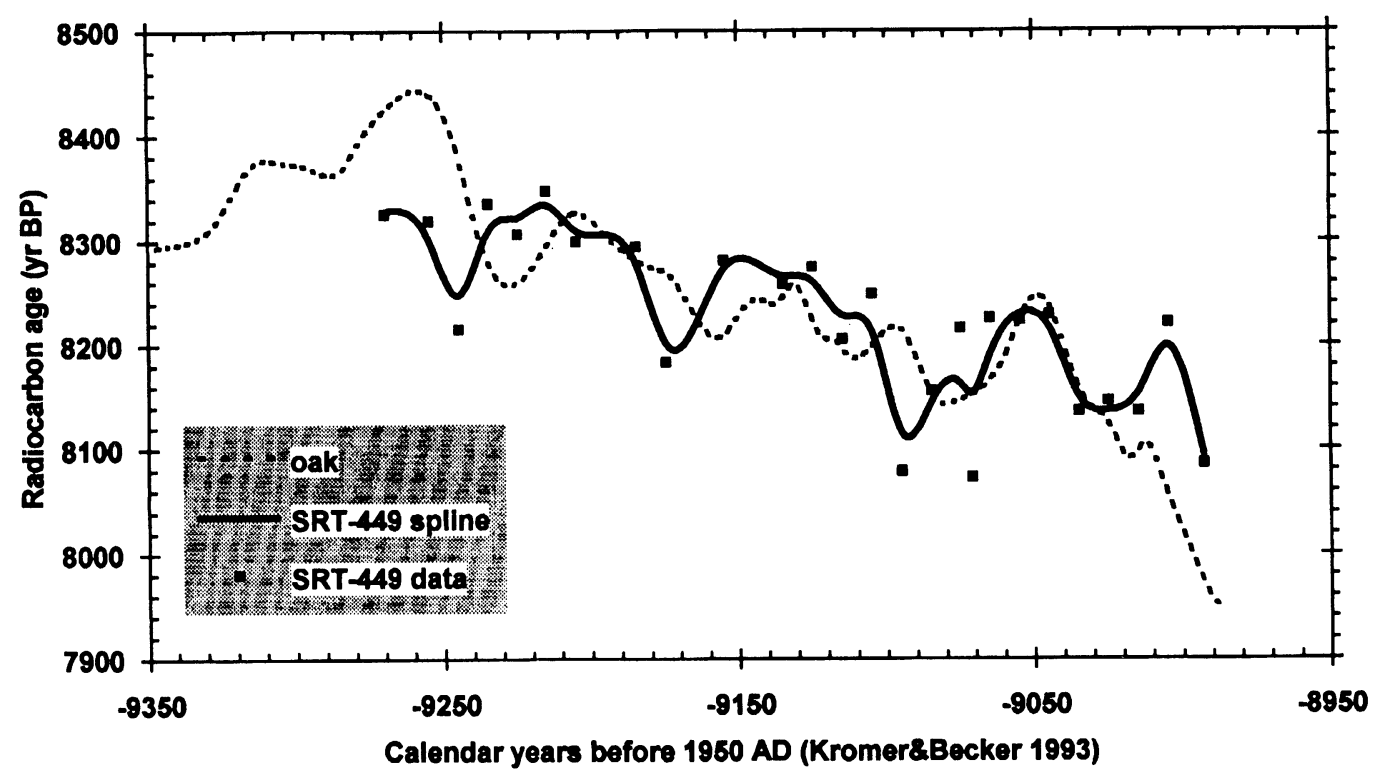

Fig. 3. Comparison of a $\sim 8200 \mathrm{BP}$ Huon pine with merged and interpolated data from German oak. $-=\mathrm{a} 30$-yr smoothing spline to ${ }^{14} \mathrm{C}$ ages ( $(\varpi)$ from Stanley River Huon pine log SRT-449, with ring 0 placed at 9281 cal BP, corresponding to minimum mean and $\mathrm{rms}$ differences. The measurements are compared with data from the Hohenheim 'Main 9' oak chronology (Kromer and Becker 1993), data from the unified German oak series with ring 0 placed at $7230 \mathrm{BC}$, i.e., $9179 \mathrm{BP}$ (Kromer $e$ t al. 1986) and data from German oak with ring 1 at $7215 \mathrm{BC}$, i.e., $9165 \mathrm{BP}$ (Stuiver $e$ t al. 1986). The oak chronologies are represented by a spline with 30 -yr smoothing fitted to the merged data sets.

sphere appearing to be slightly but not significantly younger, now occur in four data sets at 9840 9480, 9280-8990 cal BP (this paper), 8260-7910 cal BP and AD 1600-1800 (Barbetti et al. 1992), but the uncertainties, mainly due to the precision of these preliminary determinations, but also uncertainties in interlaboratory calibration, thwart quantitative carbon budgeting constraints at this stage.

Detailed intercomparisons with other laboratories are being planned, and it should be possible eventually to estimate precisely the offset between the northern and southern hemispheres during early, mid- and late Holocene times. Extension of the Tasmanian data may eventually help refine the tentative cross-match between the German Preboreal pine and the "Main 9" oak chronologies. New sections from SRT-416, from the less eroded portion of this log submerged in the river bed, have up to 449 rings that should allow us to extend younger than the plateau and into the region of steep slope at $9500-9400 \mathrm{cal} \mathrm{BP}$.

\section{ACKNOWLEDGMENTS}

We thank the Forestry Corporation, Tasmania, the Hydro Electric Commission of Tasmania and Corinna Sawmills for logistical support in the field; the Australian Research Council, the University of Sydney and the U.S. National Science Foundation (Grant EAR 93-10093 to E. Cook) for financial support. Colin Murray-Wallace and Peter Grave assisted with the ${ }^{14} \mathrm{C}$ measurements. We thank Bernd Kromer and Bernd Becker for discussion and for exchanging data with us ahead of publication. This is Lamont-Doherty Earth Observatory Contribution No. 5444. 


\section{REFERENCES}

Barbetti, M., Bird, T., Dolezal, G., Taylor, G., Francey, R. J., Cook, E. and Peterson, M., 1992. Radiocarbon variations from Tasmanian conifers: First results from late Pleistocene and Holocene logs. In Long, A. and Kra, R. S., eds., Proceedings of the 14 th International ${ }^{14} \mathrm{C}$ Conference. Radiocarbon 34(3): 806-817.

Becker, B. 1993 An 11,000-year German oak and pine dendrochronology for radiocarbon calibration. In Stuiver, M., Long, A. and Kra, R. S., eds., Calibration 1993. Radiocarbon 35(1): 201-213.

Becker, B. and Kromer, B. 1993 The continental tree-ring record - absolute chronology, ${ }^{14} \mathrm{C}$ calibration and climatic change at $11 \mathrm{ka}$. Palaeogeography, Palaeoclimatology, Palaeoecology 103: 67-71.

Broecker, W. S. and Peng, T.-H. 1992 Interhemispheric transport of carbon dioxide by ocean circulation. $\mathrm{Na}$ ture 356: 587-589

Enting, I. G. and Mansbridge, J. V. 1987 The incompatibility of ice-core $\mathrm{CO}_{2}$ data with reconstructions of biotic $\mathrm{CO}_{2}$ sources. Tellus 39B: $318-325$.

Francey, R. J., Barbetti, M., Bird, T., Beardsmore, D., Coupland, W., Dolezal, J. E., Farquhar, G. D., Flynn, R. G., Fraser, P. J., Gifford, R. M., Goodman, H. S., Kunda, B., McPhail, S., Nanson, G., Pearman, G. I., Richards, N. G., Sharkey, T. D., Temple, R. B. and Weir, B. 1984 Isotopes in tree rings - Stanley River Collections 1981/82. CSIRO Division of Atmospheric Research, Aspendale, Victoria. Technical Paper 4: 86 p.

Gupta, S. K. and Polach, H. A. 1985 Radiocarbon Dating Practices at ANU. Handbook, Research School of Pacific Studies, Canberra: 173 p.

Head, J. (ms.) 1979 Structure and chemical properties of fresh and degraded wood. M.Sc. thesis, Australian National University, Canberra: 103 p.

Kromer, B. and Becker, B. 1993 German oak and pine calibration, 7200-9400 BC. In Stuiver, M., Long, A. and Kra, R. S., eds., 1993 Calibration 1993. Radiocarbon 35(1): 125-135.

Kromer, B., Rhein, M., Bruns, M., Schoch-Fischer, H., Munnich, K. O., Stuiver, M. and Becker, B. 1986 Radiocarbon calibration data for the 6th to the 8th millennia BC. In Stuiver, M. and Kra, R. S., eds. Proceedings of the 12th International ${ }^{14} \mathrm{C}$ Conference. Radiocarbon 28(2B): 954-960.

Lerman, J. C., Mook, W. G. and Vogel, J. C. $1970{ }^{14} \mathrm{C}$ in tree rings from different localities. In Olsson, I. U., ed., Radiocarbon Variations and Absolute Chronology. Proceedings of the 12th Nobel symposium. New York, John Wiley \& Sons: 257-299.

Levin, I., Bosinger, R., Bonani, G, Francey, R., Kromer, B., Munnich, K. O., Suter, M., Trivett, N. B. A. and Wolfli, W. 1992 Radiocarbon in atmospheric carbon dioxide and methane: Global distributions and trends. In Taylor, R. E., Long, A. and Kra, R. S., eds., Radiocarbon After Four Decades: An Interdisciplinary Perspective. New York, Springer-Verlag: 503-518.

Stuiver, M., Kromer, B., Becker, B. and Ferguson, C. W. 1986 Radiocarbon age calibration back to 13,300 years $\mathrm{BP}$ and the ${ }^{14} \mathrm{C}$ age matching of the German oak and U.S. bristlecone pine chronologies. In Stuiver, M. and Kra, R. S., eds., Proceedings of the 12th International ${ }^{14} \mathrm{C}$ Conference. Radiocarbon 28(2B): 969979.

Stuiver, M., Long, A. and Kra, R. S., eds., 1993 Calibration 1993. Radiocarbon 35(1): 1-244.

Vogel, J. C., Fuls, A., Visser, E. and Becker, B., 1986 Radiocarbon fluctuations during the third millennium BC. In Stuiver, M. and Kra, R. S., eds., Proceedings of the 12th International ${ }^{14} \mathrm{C}$ Conference. Radiocarbon 28(2B): 935-938. 